\title{
Diachronic analysis of individual-tree mortality in a Norway spruce stand in the eastern Italian Alps
}

\author{
Daniele CAstagneri ${ }^{1 *}$, Emanuele LinguA ${ }^{2}$, Giorgio VAcchiano $^{1}$, Paola Nola $^{3}$, Renzo MotTA $^{1}$ \\ ${ }^{1}$ Department of AgroSelviTer, University of Turin, 10095 Grugliasco (TO), Italy \\ ${ }^{2}$ Department of TeSAF, University of Padua, Agripolis, 35020 Legnaro (PD), Italy \\ ${ }^{3}$ Department of EcoTer, University of Pavia, 27100 Pavia, Italy
}

(Received 31 March 2009; accepted 6 September 2009)

Keywords:

Picea abies (L.) Karst. / spatial pattern analysis / logistic model / competition / dendrochronology

Mots-clés :

Picea abies (L.) Karst. / analyse de modèle spatial / modèle logistique / compétition / dendrochronologie

\begin{abstract}
- Understanding tree mortality processes across time requires long term studies. Spatiotemporal patterns of mortality in a 200 years-old mono-layered Norway spruce stand were evaluated to determine what factors affected individual-tree mortality.

- We performed an analysis on two surveys (1993 and 2005) in a 1-ha permanent plot in the Paneveggio forest (Eastern Italian Alps). Tree diameter and age distribution between surveys were compared. We examined spatial patterns of living and dead trees before 1993, in 1993 and in 2005 using univariate and bivariate Ripley's $K(d)$ function, and a kernel estimator of local crowding. A logistic model was used to assess the effects of diameter, age, recent growth and competitive pressure on tree mortality.

- Spatial pattern analysis indicated mortality was associated to tree neighbourhood (neighbour effect at 2-5 m). An increment of regularization of tree spatial pattern occurred due to density-dependent mortality. Logistic regression showed tree diameter and recent growth were determinant on mortality risk during the monitoring period.

- Even if the stand is relatively aged, mortality dynamics are those typical of stem exclusion stage. Mortality was related to competitive dynamics, and small suppressed trees with slow growth rate had higher probability to die.
\end{abstract}

Résumé - Analyse diachronique de la mortalité des arbres individuels dans un peuplement d'épicéa des Alpes orientales italiennes.

- Comprendre les processus de la mortalité des arbres à travers le temps exige des études à long terme. Les modèles spatio-temporels de la mortalité dans un peuplement d'épicéa âgé de 200 ans monostrate ont été évalués afin de déterminer quels sont les facteurs qui ont un effet sur la mortalité des arbres individuels.

- Nous avons pratiqué une analyse sur deux enquêtes (1993 et 2005) dans une parcelle permanente de 1 ha dans la forêt de Paneveggio (Alpes orientales italiennes). Le diamètre des arbres et la distribution des âges ont été comparés entre les enquêtes. Nous avons examiné les modèles spatiaux des arbres vivants et des arbres morts avant 1993, en 1993 et en 2005 en utilisant des fonctions de Ripley $K(d)$ univariées et bivariées, Un modèle logistique a été utilisé pour évaluer les effets du diamètre, de l'âge, de la croissance récente et de la pression concurrentielle sur la mortalité des arbres.

- L'analyse du modèle spatial indique que la mortalité a été associée aux arbres voisins (effet du voisin distant de 2 à $5 \mathrm{~m}$ ). Un incrément de régularisation du modèle spatial de l'arbre s'est produit en raison de la dépendance de la mortalité de la densité. La régression logistique a montré que le diamètre de l'arbre et la croissance récente ont été déterminant pour le risque de mortalité au cours de la période étudiée.

- Même si le peuplement est relativement âgé, les dynamiques de la mortalité sont typiques de l'étape d'exclusion des tiges. La mortalité était liée à la dynamique concurrentielle, et de petits arbres dominés avec un faible taux de croissance avaient une probabilité supérieure de mourir.

\footnotetext{
*Corresponding author: daniele.castagneri@unito.it
} 


\section{INTRODUCTION}

Understanding and predicting tree mortality is critical in forest ecology (Franklin et al., 1987). Knowledge about mortality processes is required to increase the understanding of stand structural dynamics, improve the accuracy of forest growth models (e.g. gap models, Bugmann, 2001) and facilitate the design of sustainable management operations (Aakala et al., 2007). Moreover it is essential for ecosystem conservation, since deadwood represents an important factor for biodiversity (Harmon et al., 1986).

Tree mortality is one of the most contradictory and least measurable processes of plant population development (Taylor and MacLean, 2007). Difficulty in interpreting tree death in forests is attributed to the complexity of natural mortality processes (Monserud, 1976), that could be allogenic, i.e., due to exogenous abiotic or biotic factors, and autogenic, i.e., due to tree ageing and competitive dynamics (Peet and Christensen, 1987). More often, actual mortality patterns result from the interaction of multiple agents (Harper et al., 2006).

At the individual level, survival mostly depends on the location of immediate neighbours (Ford and Diggle, 1981): the probability of mortality is increased by proximity to trees affected by disease or pests (Taylor and MacLean, 2007), and vulnerability to windstorm may increase in absence of protection from neighbouring trees (Nagel and Diaci, 2006). Similarly, individual competition depends on distance from neighbours, hence autogenic mortality involves trees standing too close to competitors (Goreaud et al., 2002; Olano et al., 2009). However, most studies on mortality have been conducted on large plot networks (Monserud and Sterba, 1999), where explicit spatial information was not available, therefore actual tree spatial pattern was rarely taken into account.

Individual-tree mortality models have shown mortality of Norway spruce (Picea abies (L.) Karst.) to be influenced by diameter, recent growth pattern (Bigler and Bugmann, 2003; Lännenpää et al., 2008), age (Monserud and Sterba, 1999) and competition by the overstory (e.g. Eid and Tuhus, 2001). In the present study we analyzed the process and pattern of individual-tree mortality in a subalpine Norway spruce stand in the Valbona Forest Reserve (Paneveggio-Pale di San Martino Natural Park, Trentino, Italy). We chose a pure stand, undisturbed since the 1940's, growing in quite homogeneous site conditions, in order to minimize confounding factors that might mask mortality processes. No signs of heavy external disturbances such as large wind-throws, wildfires, rockfalls, insects attacks, pathogens, etc. were observed. Our aim was to evaluate what factors determine individual-tree mortality in a mature recentlyunmanaged Norway spruce stand. The analysis was conducted in a 1-ha long-term monitoring plot located inside the reserve, comparing data from two surveys (1993 and 2005).

Considering the prevalence of standing dead trees, we examined dead trees characteristics and mortality spatial pattern to verify whether mortality was induced by competition. Moreover, we evaluated changes in tree spatial pattern across time. Finally, a logistic regression was used to assess the influ-
Table I. Stand characteristics of the permanent plot in the inventory years.

\begin{tabular}{lrrr}
\hline & 1993 & 2005 & Variation \% \\
\hline Trees $\left(\mathrm{n} \mathrm{ha}^{-1}\right)$ & 557 & 510 & -8.4 \\
Basal area $\left(\mathrm{m}^{2} \mathrm{ha}^{-1}\right)$ & 65.9 & 73.7 & +11.8 \\
Quadratic mean dbh $(\mathrm{cm})$ & 38.8 & 42.9 & +10.6 \\
Mean height $(\mathrm{m})$ & 28 & 29.6 & +5.7 \\
Snag density $\left(\mathrm{n} \mathrm{ha}^{-1}\right)$ & 53 & 101 & +90.6 \\
Snag basal area $\left(\mathrm{m}^{2} \mathrm{ha}^{-1}\right)$ & 1.9 & 4.9 & +167.8 \\
Snag quad. mean dbh $(\mathrm{cm})$ & 21.4 & 24.6 & +14.9 \\
\hline
\end{tabular}

ence of diameter, age, recent growth and proximate competitive pressure on tree mortality in the 12 -y monitoring period.

\section{MATERIALS AND METHODS}

\subsection{Study site and field measurements}

The study is focused in the Valbona Forest Reserve (latitude $46^{\circ} 18^{\prime} \mathrm{N}$, longitude $11^{\circ} 45^{\prime} \mathrm{E}$ ), a 123 ha subalpine Norway spruce forest included in the Paneveggio-Pale di San Martino Natural Park (Trentino, Italy). The phytocoenosis is classified as HomogynoPiceetum subalpinum myrtilletosum. Rainfall is $1157 \mathrm{~mm} / \mathrm{year}$ at Passo Rolle (2 $002 \mathrm{~m}$ a.s.1.), approximately $3 \mathrm{~km}$ from the study site, and $1104 \mathrm{~mm} / \mathrm{y}$ at Paneveggio (1508 m a.s.l.), approximately $2 \mathrm{~km}$ from the study site. Annual mean temperature is $2.7^{\circ} \mathrm{C}$ at Passo Rolle and $3.7^{\circ} \mathrm{C}$ at Paneveggio. The bedrock is porphyry and sandstone, and soils are podsols and rankers.

Most of the Reserve is characterized by monolayered Norway spruce stands, heritage of past management. The stand analyzed herein is a monolayered pure Norway spruce stand at an elevation of $1815 \mathrm{~m}$ a.s.l. Slope (47\%), aspect (north) and microtopography appear quite homogeneous. It is relatively far from forest roads and has developed without anthropogenic influence since the 1940's, when all thinning and harvesting operations were over. Most individuals established between 1790 and 1850 (Motta et al., 1999). In 1993 a 1-ha $(100 \times 100 \mathrm{~m})$ sample plot was established to initiate long-term forest dynamics monitoring. All live trees with diameter at breast height $(\mathrm{dbh})>7.5 \mathrm{~cm}$ were identified, labelled with numbered tags and mapped. Dbh was measured for each tree. In 2005 the measurement was repeated, and dead trees with $\mathrm{dbh}>7.5 \mathrm{~cm}$ were added to the inventory. Stand characteristics are summarized in Table I.

\subsection{Dendrochronological analysis}

In 1998 an increment core was taken upslope at a height of $50 \mathrm{~cm}$ from each live tree with $\mathrm{dbh}>7.5 \mathrm{~cm}$. In order to calculate the year of establishment of dead trees, in 2005 an increment core was taken upslope from all dead trees at a height of $50 \mathrm{~cm}$. Ring width was measured to the nearest $0.01 \mathrm{~mm}$. Data were collected and stored using a LINTAB device and the TSAP package (Frank Rinn, Heidelberg). The cores were cross-dated against available site chronologies (Motta, 2002; Motta et al., 2002) in order to ensure the assignment of the correct year to each annual ring. The analysis was carried out both on cores that included a pith and on those falling 
short of the pith, whose position could be estimated by means of a graphical device (pith locator), hence the number of missing innermost rings can be calculated (Josza, 1988). In order to calculate the year of establishment, it was necessary to take into account the time to reach coring height. Since previous studies conducted in Paneveggio (Motta et al., 2002) showed that Norway spruce took an average of $18 \mathrm{y}$ to reach a height of $50 \mathrm{~cm}$, we subtracted this number to the year corresponding to the inmost ring at sampling height.

\subsection{Comparison between inventory years}

We used $t$-test and Kolmogorov-Smirnov (KS) two-sample test to compare dbh and age distributions of dead trees between inventory years (1993 and 2005), i.e. to assess if mortality involved trees having similar dbh and age. For mortality observed in 1993, we considered only snags, because logs in 1993 were regarded as snags fallen due to decomposition processes (snapped dead) (Storaunet and Rolstad, 2004), hence dead in previous period.

We used a combination of different spatial analysis techniques to investigate mortality processes. We analyzed the spatial structure of dead trees in two periods (1993 and 2005) and of live trees in three periods: before 1993, in 1993, and in 2005. For the "before 1993" analysis we considered as live all the trees and the standing dead trees present in the 1993 inventory (Zhang et al., 2009).

For each period we computed the univariate Ripley's $K(d)$ (Ripley, 1976) in order to evaluate if the spatial arrangement of live and dead trees was random, aggregate or regular. We used a square-root transformation $L(d)$ that linearizes $K(d)$ and stabilizes its variance and has an expected value of approximately zero under the Poisson assumption (Diggle, 1983). We conducted the analysis from 1 to $50 \mathrm{~m}$ (half the length of the plot side), applying a $1 \mathrm{~m}$ lag distance. The Monte Carlo technique (Besag and Diggle, 1977) (999 randomizations) was used to assess the deviation from the Complete Spatial Randomness (CSR) assumption. A correction algorithm was used to account for edge effects (Haase, 1995).

In order to evaluate spatial relationships between dead and live trees, and to assess the spatial extent of inter-tree mortality interactions, we used the $L_{12}(d)$ function, which is a generalization of $L(d)$ for a bivariate point process (Lotwick and Silverman, 1982). Since mortality in a forest stand is an event affecting a posteriori the individuals of a population (Getzin et al., 2006), the null model employed to detect this event was random labelling (Diggle, 1983; Goreaud and Pélissier, 2003). Mortality agents determine the patterns of dead trees but these can only work within the limits set by the distribution of living trees prior to the mortality events themselves (Aakala et al., 2007). In order to calculate the $99 \%$ confidence intervals, the position of all trees were maintained, but the labels "dead" and "survivor" for each tree were randomly assigned in each of the 999 Monte Carlo simulation (Diggle, 1983). Univariate and bivariate Ripley's $L(d)$ were calculated using the software SPPA 2.0 (Haase, 2001).

In order to analyze variation of local density through time we calculated local crowding intensity before 1993, in 1993 and in 2005 estimating a kernel function, i.e., a moving-window estimate of the non-constant first-order intensity $\lambda^{\mathrm{R}}(x, y)$ computed as follows:

$$
\lambda^{\mathrm{R}}(x, y)=\frac{\text { Points }\left[C_{(x, y)}(R)\right]}{\operatorname{Area}\left[C_{(x, y)}(R)\right]}
$$

where $C(x, y)(R)$ is a circular moving window with radius $R$ that is centered in cell $(x, y)$, the operator Points $[\mathrm{X}]$ counts the points in a re- gion $\mathrm{X}$, and the operator Area[X] determines the area of the region $\mathrm{X}$. Analyses were performed using the grid-based software Programita (Wiegand and Moloney, 2004). Plot surface was divided into a $1 \times 1 \mathrm{~m}$ grid and the moving window radius was set at $10 \mathrm{~m}$. A smaller moving window would too closely mimic the original pattern, while a larger one approximates CSR (Wiegand and Moloney, 2004). A firstorder intensity map showing $\lambda^{\mathrm{R}}(x, y)$ values for all grid cells $(1 \mathrm{~m})$ in the plot was obtained for each period. Skewness and kurtosis of cell frequency distributions were scrutinized to evaluate the change of local density through time.

\subsection{Mortality model}

Since mortality is a discrete event, the logistic function is widely used to determine the influences of explicatory variables on individual tree mortality (Monserud, 1976). We performed a binomial logistic regression to evaluate probability of survival in the observation period (1993-2005) using the software SPSS 16.0 (SPSS Inc., Chicago IL):

$$
P S=\left(1+e^{-\beta^{\prime} X}\right)^{-t}
$$

where $P S$ is the probability of survival over a period of $t$ years. $\beta^{\prime} X$ is a linear combination of parameters $\beta$ and the explicatory variables $X$. Independent variables were entered by a stepwise process. Models accuracy was evaluated as the percentage of dead trees correctly classified and as the overall accuracy (prediction for dead and live trees) (Bigler, Bugmann, 2004). Nagelkerke's $R^{2}$ and Hosmer-Lemeshow goodness-of-fit were used as well (see Crecente-Campo et al., 2009, for further details).

The aim of this analysis was to evaluate the effects of dbh, age, recent growth and neighbourhood on mortality probability (complementary of probability of survival, $1-P S$ ). Diameter of focal trees is generally included in mortality models, since density-dependent mortality usually involves smaller trees. Age is related to juvenile mortality or senescence. Recent growth was calculated as the Basal Area Increment (relBAI) of focal trees in 1993. RelBAI assesses individual tree vitality before the analysis period (Bigler, Bugmann, 2004). Since in many suppressed and dead trees growth rings were extremely narrow (Cherubini et al., 1996), and several missing rings occurred, we calculated relBAI for 10 and 30 y before 1993 (Antos et al., 2008). Tree survival finally depends on the location of immediate neighbours (Ford and Diggle, 1981). We assessed neighbourhood as the sum of basal area (BA) of trees located within the area of influence (Kenkel, 1988) of each focal tree. Analysis was performed using kriging interpolation implemented with ArcView ${ }^{\circledR}$ geographic information system software. The radius of the area of influence was estimated from bivariate Ripley's $K(d)$ function. An adjustment for edge effect was applied.

We tested three models: in the first one we included dbh, age and BA of neighbours, while in the second and in the third model relBAI (1964-1993 and 1984-1993 respectively) was also included.

Even if competition had a long-term negative impact on growth rate in this plot (Castagneri et al., 2008), tree rings are integrator of biotic and abiotic influences, and it is hard to distinguish neighbour effect signal. To analyse neighbour effect on mortality, we used model 1.

Moreover, dendrochronological analysis is time demanding, and simulation studies normally rely on the predicted rather than on measured increment (Crecente-Campo et al., 2009), thus we tested model 1 not including recent growth information. However, tree-rings 

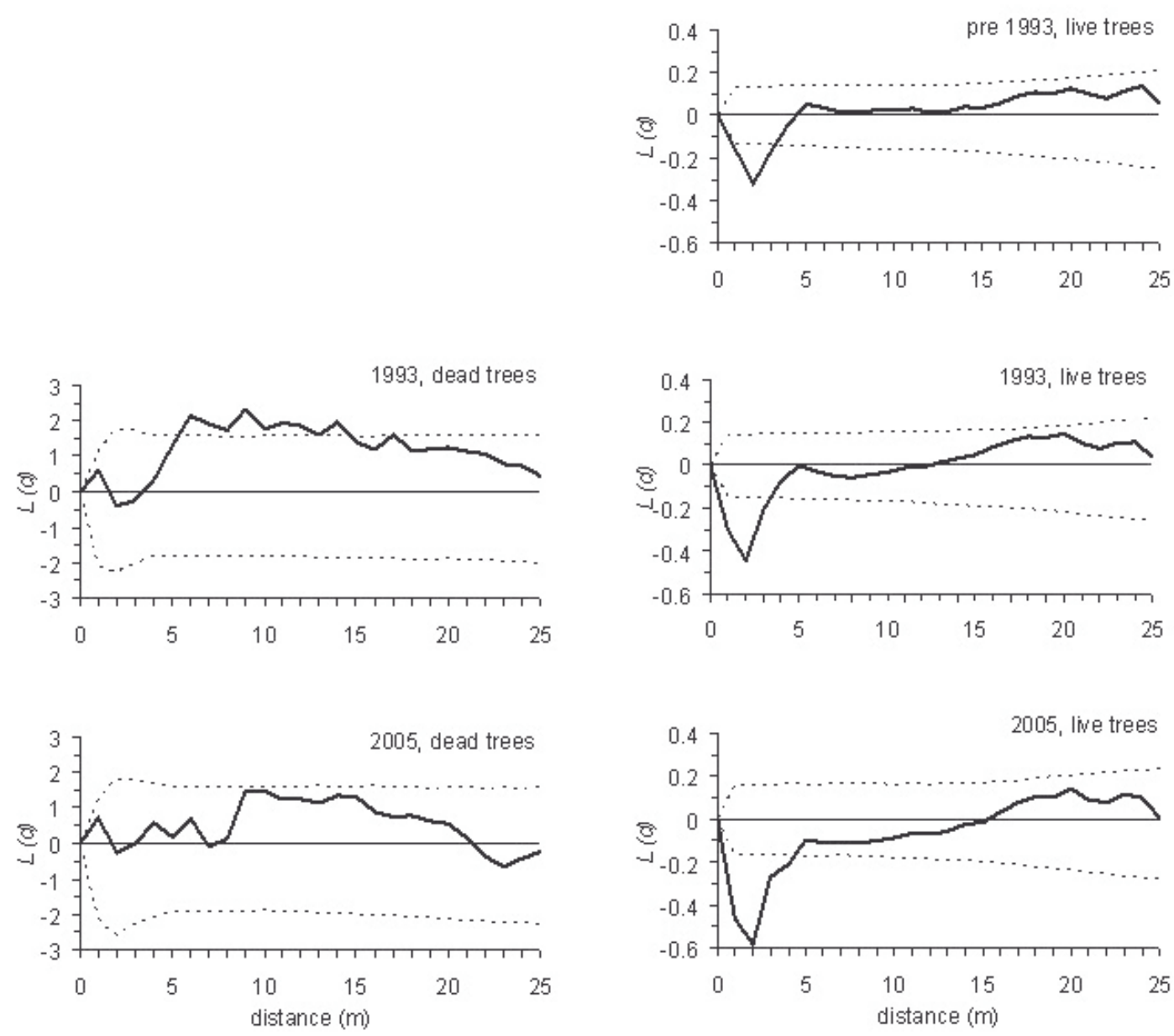

Figure 1. Univariate Ripley's $K$ analysis for alive trees and snags in different periods. The solid line represents $L(d)$; the two broken lines represent the Monte Carlo envelope constructed at 99\% confidence level. Values above confidence limit indicate clustering, whereas values below indicate hyperdispersion. Analyses were performed from 1 to $50 \mathrm{~m}$. Over $25 \mathrm{~m}$ functions did not diverge from null hypothesis, thus only results up to $25 \mathrm{~m}$ were shown.

are more informative than competitive measurement on whole growth history of a tree (Bigler and Bugmann, 2003), and a higher performance of model 2 and 3 was expected.

\section{RESULTS}

\subsection{Comparison between inventory years}

In the $12 \mathrm{y}$ monitoring period mortality rate has been $0.8 \%$ year $^{-1}$ (48 snags and 4 uprooted logs on 557 live trees) (Tab. I). Trees dead before 1993 were smaller in dbh (mean value: $19.5 \mathrm{~cm})$ than trees dead after $1993(26.2 \mathrm{~cm})(t$-test, $p<0.001)$ and their size distributions differed significantly (KS test, $p<0.001$ ).

We determined the establishment year of 31 out of 53 trees dead before 1993 and of 37 out of 52 trees dead between 1993 and 2005. $t$-test and KS test did not indicate significant differences in the mean and frequency distribution of tree ages.

The spatial pattern of live trees deviated significantly from CSR at short distances, exhibiting pronounced changes across time. Ripley's $L(d)$ function showed a regular distribution of live trees at distances $<4 \mathrm{~m}$ before 1993, and more so in the following inventory years (Fig. 1). Trees dead before 1993 were aggregated at $d=5$ to $15 \mathrm{~m}$, but the pattern did not significantly deviate from a random one in the following period (Fig. 1).

In the monitoring period we observed a positive association between live and dead trees. Bivariate analysis based on random labelling null model showed a significant positive correlation in 1993 for distances $<3 \mathrm{~m}$, and an even stronger positive correlation in 2005 for distances $<6 \mathrm{~m}$ (Fig. 2).

Local crowding maps (Fig. 3) showed a decrease in heterogeneity across time. This trend was confirmed by statistical analysis of local density values. Mean cell value decreased with time, from 17.82 trees in the $10 \mathrm{~m}$ moving window before the first tally to 15.00 in 2005 , because of mortality. Standard deviation decreased from 4.22 to 3.40. Local density value had a leptokurtic distribution at all tallies. Pearson's kurtosis value was higher in 2005 (0.273) and in 1993 (0.264) than before 1993 (0.134), indicating a decrease in the frequency of low- 

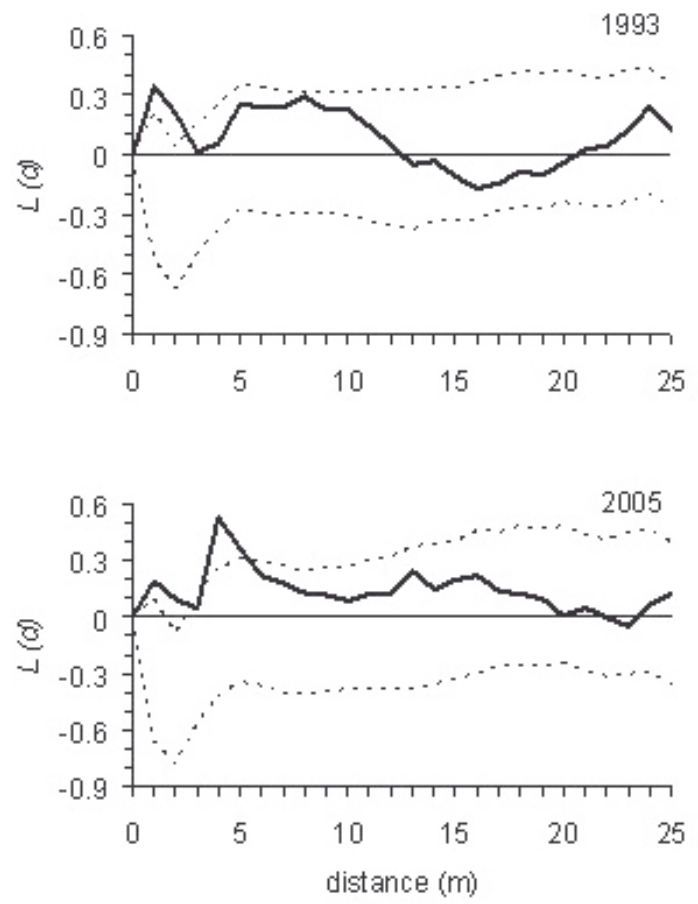

Figure 2. Bivariate Ripley's $K_{12}$ analysis in different periods tested against random labelling null hypothesis. The solid line represents $L_{12}(d)$; the two broken lines represent the Monte Carlo envelope constructed at $99 \%$ confidence level. Values above confidence limit indicate positive spatial interactions between live trees and snags, whereas values below indicate negative spatial interactions. Analyses were performed from 1 to $50 \mathrm{~m}$. Over $25 \mathrm{~m}$ functions did not diverge from null hypothesis, thus only results up to $25 \mathrm{~m}$ were shown.

and high-density across time. Moreover, cell distributions in 1993 and in 2005 shifted to low values (Skewness value = 0.032 before $1993 ; 0.207$ in $1993 ; 0.431$ in 2005).

\subsection{Mortality model}

Model 1 correctly predicted the status of $75.7 \%$ of dead trees and $77.8 \%$ of living trees, and overall accuracy was $77.6 \%$ (Tab. II). Hosmer-Lemeshow $p$ was higher than 0.05 , but fit of the model was quite low. Model 2 (relBAI 1984-1993) and 3 (relBAI 1964-1993) had a higher number of both dead and live trees correctly predicted than model 1 , hence a higher overall accuracy occurred $\left(85.1 \% ; 83.7 \%\right.$ respectively). Moreover, Nagelkerke's $R^{2}$ and Hosmer-Lemeshow $p$ were higher. Model 2 had a slightly better overall accuracy and $R^{2}$ than model 3 .

Dbh was a highly significant variable in all models, indicating that mortality involved mainly small size classes. Age was never significant. In both model 2 and 3 relBAI was highly significant, indicating that recent growth strongly improved the model. However in model 2 odds ratio was lower than in model 3, indicating relBAI 1984-1993 had a stronger positive effect in survival probability.
Table II. Estimated parameters and fit statistics of the logistic models.

\begin{tabular}{|c|c|c|c|c|}
\hline \multirow{2}{*}{$\begin{array}{l}\text { Model } \\
\text { Variables }\end{array}$} & & 1 & 2 & 3 \\
\hline & & & & \\
\hline \multirow[t]{2}{*}{ Intercept } & Estimate & -1.663 & 2.963 & 3.455 \\
\hline & Sig. & 0.183 & 0.103 & 0.067 \\
\hline \multirow[t]{3}{*}{ Dbh 1993} & Estimate & -0.129 & -0.059 & -0.081 \\
\hline & Sig. & 0.000 & 0.014 & 0.001 \\
\hline & Odds ratio & 0.879 & 0.942 & 0.922 \\
\hline \multirow[t]{3}{*}{ BA neighbours } & Estimate & 0.017 & 0.000 & 0.003 \\
\hline & Sig. & 0.040 & 0.986 & 0.710 \\
\hline & Odds ratio & 1.017 & n.s. & n.s. \\
\hline \multirow[t]{3}{*}{ Age 1993} & Estimate & 0.012 & -0.009 & -0.009 \\
\hline & Sig. & 0.125 & 0.390 & 0.392 \\
\hline & Odds ratio & n.s. & n.s. & n.s. \\
\hline \multirow[t]{3}{*}{ RelBAI 1984-1993 } & Estimate & & -0.338 & \\
\hline & Sig. & & 0.000 & \\
\hline & Odds ratio & & 0.713 & \\
\hline \multirow[t]{3}{*}{ RelBAI 1964-1993 } & Estimate & & & -0.079 \\
\hline & Sig. & & & 0.000 \\
\hline & Odds ratio & & & 0.924 \\
\hline \multicolumn{2}{|c|}{ Producer's accuracy dead \% } & 75.7 & 80.6 & 83.3 \\
\hline \multicolumn{2}{|c|}{ Producer's accuracy living $\%$} & 77.8 & 85.5 & 83.7 \\
\hline \multicolumn{2}{|l|}{ Overall accuracy } & 77.6 & 85.1 & 83.7 \\
\hline \multicolumn{2}{|l|}{ Nagelkerke $R^{2}$} & 0.244 & 0.459 & 0.424 \\
\hline \multicolumn{2}{|c|}{$p$ (Hosmer-Lemeshow) } & 0.078 & 0.628 & 0.849 \\
\hline
\end{tabular}

In model 1 , BA of neighbours was significant $(p<0.05)$. However, it was not significant in models including relBAI, probably because those variables were correlated $(r=-0.229$; $p<0.01$ with relBAI 1984-1993). Since recent growth is caused by different factors that are also responsible of survival probability, it is a best descriptor of tree condition than neighbourhood alone, hence in the stepwise selection it was preferred to neighbour BA.

\section{DISCUSSION}

In the study plot pre-1993 mortality mostly involved small diameter classes, while in the following period it focused on mid-size trees as well. Tree mortality heavily changed the forest structure, since smaller diameter classes were almost absent from the last inventory.

Mortality observed in 1993 was clustered, while mortality in 2005 was not. However, that result alone is not sufficient to infer the cause of mortality, because cluster mortality could be due to allogenic mortality causes (Cherubini et al., 2002; Dobbertin et al., 2001), or to self-thinning in an heterogeneous environment (Getzin et al., 2008) or in a non-homogeneously distributed stand (Wiegand and Moloney, 2004).

The positive interaction between live and dead trees in the plot indicated death probability was not the same for all individuals but it depended on neighbours (Goreaud and Pélissier, 
(a)

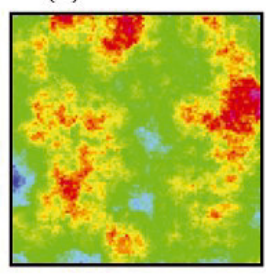

High tree density

Low tree density (b)

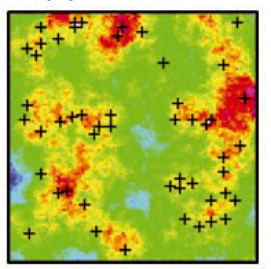

+ Dead trees (c)

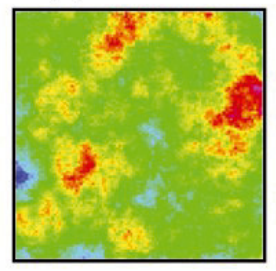

$N$

(d)

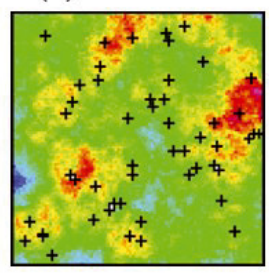

(e)

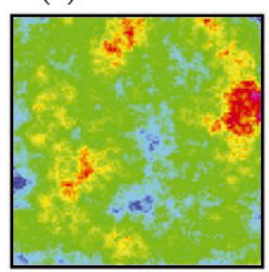

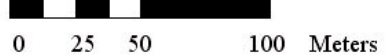

Figure 3. Kernel density of living trees in the three periods (a, c, e) and location of snags observed in 1993 (b) and in 2005 (d). Pixel size is $1 \mathrm{~m} \times 1 \mathrm{~m}$. (A color version of this figure is available at www.afs-journal.org.)

2003). At small spatial scale dead trees were positively associated to live trees due to the death of trees standing too close to competitors, pointing out the importance of small-scale competition in mortality dynamics (Hou et al., 2004; Wolf, 2005). The space around an individual where mortality is higher than expected under random conditions delineates the "area of influence", where the effect of competition is intense enough to determine mortality of neighbours (Kenkel, 1988; Ward et al. 1996). The mean area of influence increased during the observation period, indicating an increase in competitive pressure as the stand developed. Several suppressed trees 2 to $5 \mathrm{~m}$ apart from competitors were alive in 1993, but they died in the following period. Results were consistent with those in dense mature Norway spruce stands in Czech Republic (neighbour effect at 2-5 m) (Vacek and Lepš, 1996), and in open-canopy mature Picea-Betula stands in Finland (neighbour effect at 0-4 m) (Doležal et al., 2006).

As a result of mortality, local density pattern changed in the observation period. There was an increment of regularization at distance lower than $6 \mathrm{~m}$, as a consequence of mortality of suppressed trees close to neighbours. Moreover we observed a decrease of high-density patches and consequently an increment of medium-low density patches, resulting in a more homogeneous spatial pattern. Many studies on spatial pattern development have shown a shift from aggregated or random distribution in early stand phases to uniform or overdispersed distribution in later stages, as competition for limiting resources negatively affects survival in close proximity of other trees (Wolf, 2005). This trend is consistent with that observed in the stand analyzed herein.

Spatial analyses supported prediction about mortality process, i.e. mortality observed in the plot between 1993 and 2005 was mainly caused by competition. Considering that, we discuss the effect of descriptive variables on tree mortality.

Models prediction accuracy was comparable to similar works on Norway spruce mortality (Bigler and Bugmann, 2004; Eid and Tuhus, 2001). Several descriptive variables were available, including dendrochronological and spatial pattern information. However models were fitted on a restricted dataset (1 ha), and general conclusion on Norway spruce mortality can not be inferred.

Diameter was a critical variable in determining mortality likelihood in our plot, as usually observed in mortality of Norway spruce stands (Monserud and Sterba, 1999). The effect of tree size on competitiveness and survivorship is consistent with density-dependent mortality patterns: mortality rate increases as size decreases, since small trees have lower chances of competing for resources (Uriarte et al., 2004).

Trees dead in the observation period were coeval of live trees, indicating that establishment period did not influence death probability. In the even-aged stand analyzed herein, where most individuals established across a time span of $60 \mathrm{y}$, senescence did not significantly influence mortality risk, and mortality involved smaller but not younger trees.

In high density stands individual mortality is related to the size of competitors. Majority of mortality models were computed over large areas using non-spatial models, and competition was expressed as the size of competitors in the plot (e.g. BA of trees larger than focal tree, Eid and Tuhus, 2001). However, density-dependent mortality was related to neighbourhood around individual (Goreaud and Pélissier, 2003). Our analysis demonstrated that individual survival likelihood depended on the size of neighbours within the area of influence of the focal tree.

Recent growth was an important indicator of individual survival likelihood. As expected, relBAI 1984-1993 had a stronger relation with survival likelihood compared to relBAI 1964-1993, since it was more related to the recent years condition of the tree.

Tree rings provide information about recent history of the focal tree (Cherubini et al., 2002; Dobbertin, 2005; Wyckoff and Clark, 2000). They are a direct measurement of the constraints experienced by the tree during growth, thus they are more informative than indirect measurements, such as the size of neighbours. However, in absence of dendrochronological data, neighbourhood indices can provide information about competitive pressure on the trees, indicating trees more likely to die. 


\section{CONCLUSION}

The importance of long term and repeated studies of forest stand is well recognized (Turner et al., 2003). Mortality dynamics are best observed by repeatedly tallying populations for a decade or more, and this usually reveals characteristic pulses and trends in spatial patterns through time (Peterken, 1996).

Even if the stand is relatively aged (most of the trees have more than 180 y) the competitive mortality dynamics observed in the plot are those typically observed in the last phases of the stem exclusion stage (Oliver and Larson, 1996). Our analysis showed variations in live and dead trees pattern across time, and indicated that probability of tree death depended on local crowding. Trees having low chances to acquire resources (small dbh) and with slow growth rate had higher probability to die. Moreover we observed a regularization of spatial structure both at individual and at plot scale, so we can infer that intraspecific competition was the primary cause of mortality during recent decades.

In upcoming years, we expect an increment of competitive pressure (Castagneri et al., 2008) and mortality involving mainly suppressed trees in the "area of influence" of bigger neighbours. Besides we expect an increment of the allogenic mortality involving the creation of gaps as already observed in the Reserve (Motta et al., unpublished data), thus an increment of deadwood biomass and a levelling or decline of live biomass as mortality breaks up the dominant canopy of trees (Smith and Long, 2001).

Acknowledgements: We thank the "Parco Naturale Paneveggio-Pale di S. Martino" for logistic support. Thanks to Roberta Berretti for field work and Jeanne Griffin for revising English.

\section{REFERENCES}

Aakala T., Kuuluvainen T., De Grandpre L., and Gauthier S., 2007. Trees dying standing in the northeastern boreal old-growth forests of Quebec: spatial patterns, rates, and temporal variation. Can. J. For. Res. 37: 50-61.

Antos J.A., Parish R., and Nigh G.D., 2008. Growth patterns prior to mortality of mature Abies lasiocarpa in old-growth subalpine forests of southern British Columbia. For. Ecol. Manage. 255: 1568-1574.

Besag J. and Diggle P.J., 1977. Simple Monte Carlo tests for spatial patterns. Appl. Stat. 26: 327-333.

Bigler C. and Bugmann H., 2003. Growth-dependent tree mortality models based on tree rings. Can. J. For. Res. 33: 210-221.

Bigler C. and Bugmann H., 2004. Predicting the time of tree death using dendrochronological data. Ecol. Appl. 14: 902-914.

Bugmann H., 2001. A review of forest gap models. Clim. Change 51: 259-305.

Castagneri D., Vacchiano G., Lingua E., and Motta R., 2008. Analysis of intraspecific competition in two subalpine Norway spruce (Picea abies (L.) Karst.) stands in Paneveggio (Trento, Italy). For. Ecol. Manage. 255: 651-659.

Cherubini P., Fontana G., Rigling D., Dobbertin M., Brang P., and Innes J.L., 2002. Tree-life history prior to death: two fungal root pathogens affect tree-ring growth differently. J. Ecol. 90: 839-850.
Cherubini P., Piussi P., and Schweingruber F.H., 1996. Spatiotemporal growth dynamics and disturbances in a subalpine spruce forest in the Alps: A dendroecological reconstruction. Can. J. For. Res. 26: 9911001.

Crecente-Campo F., Marshall P., and Rodriguez-Soalleiro R., 2009. Modeling non-catastrophic individual-tree mortality for Pinus radiata plantations in northwestern Spain. For. Ecol. Manage. 257: 15421550.

Diggle P.J., 1983. Statistical analysis of spatial point patterns. Academic Press, New York.

Dobbertin M., 2005. Tree growth as indicator of tree vitality and of tree reaction to environmental stress: a review. Eur. J. For. Res. 124: 319_ 333.

Dobbertin M., Baltensweiler A., and Rigling D., 2001. Tree mortality in an unmanaged mountain pine (Pinus mugo var. uncinata) stand in the Swiss National Park impacted by root rot fungi. For. Ecol. Manage. 145: 79-89.

Doležal J., Srutek M., Hara T., Sumida A., and Penttila T., 2006. Neighborhood interactions influencing tree population dynamics in nonpyrogenous boreal forest in northern Finland. Plant Ecol. 185: $135-150$.

Eid T. and Tuhus E., 2001. Models for individual tree mortality in Norway. For. Ecol. Manage. 154: 69-84.

Ford E.D. and Diggle P.J., 1981. Competition for light in a plant monoculture modelled as a spatial stochastic process. Ann. Bot. 48: 481-500.

Franklin J.F., Shugart H.H., and Harmon M.E., 1987. Tree death as an ecological process. BioScience 37: 550-556.

Getzin S., Dean C., He F.L., Trofymow J.A., Wiegand K., and Wiegand T., 2006. Spatial patterns and competition of tree species in a Douglas-fir chronosequence on Vancouver Island. Ecography 29: 671-682.

Getzin S., Wiegand K., Schumacher J., and Gougeon F.A., 2008. Scaledependent competition at the stand level assessed from crown areas. For. Ecol. Manage. 255: 2478-2485.

Goreaud F. and Pelissier R., 2003. Avoiding misinterpretation of biotic interactions with the intertype K-12-function: population independence vs. random labelling hypotheses. J. Veg. Sci. 14: 681-692.

Goreaud F., Loreau M., and Millier C., 2002. Spatial structure and the survival of an inferior competitor: a theoretical model of neighbourhood competition in plants. Ecol. Model. 158: 1-19.

Haase P., 1995. Spatial pattern-analysis in ecology based on Ripley Kfunction - introduction and methods of edge correction. J. Veg. Sci. 6: 575-582.

Haase P., 2001. Can isotropy vs. anisotropy in the spatial association of plant species reveal physical vs. biotic facilitation? J. Veg. Sci. 12: $127-136$.

Harmon M.E., Franklin J.F., Swanson F.J., Sollins P., Gregory S.V., Lattin J.D., Anderson N.H., Cline S.P., Aumen N.G., Sedell J.R., Lienkaemper G.W., Cromack K., and Cummins K.W., 1986. Ecology of coarse woody debris in temperate ecosystems. Adv. Ecol. Res. 15: $133-302$.

Harper K.A., Bergeron Y., Drapeau P., Gauthier S., and De Grandpre L., 2006. Changes in spatial pattern of trees and snags during structural development in Picea mariana boreal forests. J. Veg. Sci. 17: 625636.

Hou J.H., Mi X.C., Liu C.R., and Ma K.P., 2004. Spatial patterns and associations in a Quercus-Betula forest in northern China. J. Veg. Sci. 15: 407-414.

Josza L., 1988. Increment core sampling techniques for high quality cores. Forintek, sp-30, Special Publication, Vancouver, BC.

Kenkel N.C., 1988. Pattern of self-thinning in jack pine: testing the random mortality hypothesis. Ecology 69: 1017-1024. 
Lännenpäa A., Aakala T., Kauhanen H., and Kuuluvainen T., 2008. Tree mortality agents in pristine Norway spruce forests in northern Fennoscandia. Silva Fenn. 42: 151-163.

Lotwick H.W. and Silverman B.W., 1982. Methods for analysing spatial processes of several types of points. J. Roy. Stat. Soc. B. 44: 406413.

Monserud R.A., 1976. Simulation of forest mortality. For. Sci. 22: 438444.

Monserud R.A. and Sterba H., 1999. Modeling individual tree mortality for Austrian forest species. For. Ecol. Manage. 113: 109-123.

Motta R., 2002. Old-growth forests and silviculture in the Italian Alps: the case-study of the strict reserve of Paneveggio (TN). Plant Biosyst. 136: 223-231.

Motta R., Nola P., and Piussi P., 1999. Structure and stand development in three subalpine Norway spruce (Picea abies (L.) Karst.,) stands in Paneveggio (Trento, Italy). Global Ecol. Biogeogr. 8: 455-471.

Motta R., Nola P., and Piussi P., 2002. Long-term investigations in a strict forest reserve in the eastern Italian Alps: spatio-temporal origin and development in two multi-layered subalpine stands. J. Ecol. 90: 495507.

Nagel T.A. and Diaci J., 2006. Intermediate wind disturbance in an oldgrowth beech-fir forest in southeastern Slovenia. Can. J. For. Res. 36: 629-638.

Olano J.M., Laskurain N.A., Escudero A., and De La Cruz M., 2009. Why and where do adult trees die in a young secondary temperate forest? The role of neighbourhood. Ann. For. Sci. 66: 105.

Oliver C.D. and Larson B.C., 1996. Forest Stand Dynamics. John Wiley $\&$ Sons, New York, $520 \mathrm{p}$.

Peet R.K. and Christensen, N.L., 1987. Competition and tree death. BioScience 37: 586-595.

Peterken G.F., 1996. Natural Woodland. Ecology and conservation in northern temperate regions. Cambridge Univeristy Press, Cambridge.
Ripley B.D., 1976. The second-order analysis of stationary point processes. J. Appl. Prob. 13: 255-266.

Smith F.W. and Long J.N., 2001. Age-related decline in forest growth: an emergent property. For. Ecol. Manage. 144: 175-181.

Storaunet K.O. and Rolstad J., 2004. How long do Norway spruce snags stand? Evaluating four estimation methods. Can. J. For. Res. 34: 376383.

Taylor S. and MacLean D.A., 2007. Spatiotemporal patterns of mortality in declining balsam fir and spruce stands. For. Ecol. Manage. 253: 188-201.

Turner M.G., Collins S.L., Lugo A.E., Magnuson J.J., Rupp T.S., and Swanson F.J., 2003. Disturbance dynamics and ecological response: the contribution of long-term ecological research. BioScience 53: $46-56$.

Uriarte M., Canham C.D. Thompson, J., and Zimmerman J.K., 2004. A neighborhood analysis of tree growth and survival in a hurricanedriven tropical forest. Ecol. Monographs 74: 591-614.

Vacek S. and Lepš J., 1996. Spatial dynamics of forest decline: The role of neighbouring trees. J. Veg. Sci. 7: 789-798.

Ward J.S., Parker G.R., and Ferrandino F.J., 1996. Long-term spatial dynamics in an old-growth deciduous forest. For. Ecol. Manage. 83: 189-202

Wiegand T. and Moloney K.A., 2004. Rings, circles, and null-models for point pattern analysis in ecology. Oikos 104: 209-229.

Wolf A., 2005. Fifty year record of change in tree spatial patterns within a mixed deciduous forest. For. Ecol. Manage. 215: 212-223.

Wyckoff P.H. and Clark J.S., 2000. Predicting tree mortality from diameter growth: a comparison of maximum likelihood and Bayesian approaches. Can. J. For. Res. 30: 156-167.

Zhang J., Hao Z., Sun I.F., Song B., Ye J., Li B., and Wang X., 2009. Density dependence on tree survival in an old-growth temperate forest in northeastern China. Ann. For. Sci. 66: 204. 